\title{
Transplacental infection in goats experimentally infected with a European strain of bluetongue virus serotype 8
}

Peter Coetzee $^{\mathrm{a}, \mathrm{b},{ }^{*}, \text { Maria Stokstad }^{\mathrm{b}}, \text { Mette Myrmel }^{\mathrm{c}} \text {, Paidamwoyo Mutowembwa }}{ }^{\mathrm{d}}$, Torleiv Loken $^{\mathrm{b}}$, Estelle. H. Venter ${ }^{\mathrm{a}}$, Moritz Van Vuuren ${ }^{\mathrm{a}}$.

${ }^{a}$ Department of Veterinary Tropical Diseases, Faculty of Veterinary Medicine, University of Pretoria, Private Bag X04, Onderstepoort, Pretoria, 0110, South Africa

${ }^{\mathrm{b}}$ Department of Production Animal Clinical Sciences, Norwegian School of Veterinary Science, P. O. Box 8146, Department 0033, Oslo, Norway

${ }^{\mathrm{c}}$ Department of Food Safety and Infection Biology, Norwegian School of Veterinary Science, P. O. Box 8146, Oslo, Norway

${ }^{\mathrm{d}}$ Exotic Diseases Division, Onderstepoort Veterinary Institute, Private Bag 5, Onderstepoort, Pretoria, 0110, South Africa

* Corresponding author. Tel.: +27 826874230

Email address: peter.coetzee@yahoo.com (P. Coetzee). 


\section{Transplacental infection in goats experimentally infected with a European strain of bluetongue virus serotype 8}

\section{Abstract}

The capability of the current European strain of bluetongue virus serotype 8 (BTV-8) to cross the ruminant placenta has been established in experimental and field studies in both sheep and cattle. Sero-prevalence rates in goats in north-western Europe were high during the recent outbreak of BTV-8, however the capability of the virus to infect goats through the transplacental route has not been established. In the present study, four Saanen goats pregnant at 62 days of gestation were inoculated with the European strain of BTV-8, in order to investigate the capability of the virus to cross the caprine placenta. Infection of adult goats resulted in mild clinical signs, however gross lesions observed post mortem were more severe. Viral RNA was detected by real-time RT-PCR in blood and tissue samples from three foetuses harvested from two goats at 43 days post infection. Conventional RT-PCR and sequencing targeting genome segment 2 confirmed infection of brain tissue from two of these foetuses with BTV-8. Viral RNA was also detected in placental tissue from the remaining two goats at 13-25 dpi, although infection of the two foetuses carried by these animals could not be established. In total, five of six foetuses demonstrated lesions that may have been associated with transplacental infection with BTV, which in one foetus included a circular patch of haemorrhage at the base of the pulmonary artery. Infected foetuses did not demonstrate neurological lesions. Low viral RNA levels in foetal blood and tissue further suggest that the infected foetuses would probably not have been born viraemic. The implication of these findings with regards to the epidemiology and overwintering of BTV-8 in Europe remains unclear. 
Keywords: Goats, transplacental infection, bluetongue, bluetongue virus serotype 8, Europe, overwintering.

\section{Introduction}

Bluetongue (BT) is a globally important viral haemorrhagic disease of domestic and wild ruminants (and in particular of sheep) that is caused by the arthropod transmitted bluetongue virus (BTV) (Orbivirus genus, family Reoviridae) (Borden et al., 1971; Mertens et al., 2005). Twenty six serotypes of the virus have been identified (Howell, 1960; Howell et al., 1970; Maan et al., 2007; Hofmann et al., 2008; Maan et al., 2011) based either on serotype-specific neutralisation of the viral outer capsid protein VP2 (Huismans and Erasmus, 1981; Huismans et al., 1987; Mertens et al., 1989) or analysis of VP2 amino acid sequence data (Hoffman et al., 2008; Maan et al., 2007; Maan et al., 2011). Bluetongue virus is transmitted primarily through the bites of haematophagous midges (Culicoides spp. - Diptera: Ceratopogonidae), the biological vectors of the virus (Du Toit, 1944). The distribution of the virus is closely linked to the distribution of vector competent midge species and suitable climatic conditions that support the seasonal circulation of the virus. The virus therefore occurs mainly in tropical and subtropical regions of the world between the latitudes of $40-50^{\circ} \mathrm{N}$ and $35^{\circ} \mathrm{S}$ (Tabachnick, 2004).

The global distribution of BTV has changed dramatically over the last two decades. This change in distribution has been particularly prominent in Europe, where several strains and serotypes have since 1998 caused outbreaks far north of the virus' traditional range in Northern Africa and the Mediterranean basin (Purse et al., 2005). The most economically damaging 
outbreak of BT recorded in Europe started in 2006, when a strain of bluetongue virus serotypes 8 (BTV-8) was introduced through an unknown route into north-western Europe. The virus surprisingly managed to persist during the 2006-2007 winter period and re-emerged in May-June of 2007. During that year the virus spread to several additional European countries and affected over 55000 holdings, resulting in economic losses totalling hundreds of millions of Euros (Maan et al., 2008; Velthuis et al., 2010).

Several characteristics of the 2006-2008 outbreak of BTV-8 in north-western Europe made it unusual when compared to BT outbreaks which have been caused by other strains and serotypes in other regions of the world. The virus was spread by Palearctic midge species (Meiswinkel et al., 2008) and appeared to be highly virulent, causing clinical disease not only in sheep, but also in cattle and goats (Thiry et al., 2006; Dercksen et al., 2007; Dal Pozzo et al., 2009). It was also observed that infection of pregnant sheep and cattle resulted in a high incidence of reproductive failures including abortions, still births and malformations in offspring, suggesting that the virus had acquired the capability to cross the ruminant placenta (Wouda et al., 2008; Vercauteren et al., 2008; Desmecht et al., 2008). Prior to the European outbreak of BTV-8, transplacental infection had generally only been associated with the vaccination of pregnant sheep and cattle with egg and cell culture adapted modified-live virus (MLV) vaccines of South African and American origin (Kirkland and Hawkes, 2004), whereas wild-type strains were generally thought to be incapable of doing so. Therefore it was initially speculated that the BTV-8 outbreak was caused either by an MLV strain or a wild-type virus that had reassorted its genome segments with a MLV strain (Maan et al., 2008). 
Transplacental infection with the current European strain of BTV-8 has been investigated extensively in both sheep and cattle in experimental (Worwa et al., 2009; Backx et al., 2009; van der Sluijs et al., 2011) and field studies (De Clercq et al., 2008; Darpel et al., 2009a; SantmanBerends et al., 2010; Saegerman et al., 2010) in north-western Europe. Field surveys have indicated that the virus was extremely efficient at crossing the placenta. For example, transmission rates of $33-41 \%$ were recorded amongst calves born to previously infected dams in the field in the Netherland, Belgium and the United Kingdom (2007-2008) (Darpel et al., 2009; De Clercq et al., 2008; Desmecht et al., 2008). The high frequency with which the BTV-8 strain was able to cross the placenta may have been a contributing factor that allowed the virus to persist during the adult vector free/low European winters. Several studies conducted in northwestern Europe have demonstrated the birth of seemingly healthy PCR positive and/or viraemic lambs or calves, some of which tested positive for viral RNA for several months (De Clercq et al., 2008; Menzies et al., 2008; Santman-Berends et al., 2010; Saegerman et al., 2010). These animals may have served as a source of virus for newly emerged adult midges in subsequent vector seasons.

In August 2007 BT was reported for the first time in goats in the Netherlands. Despite the apparent susceptibility of goats to infection with BTV-8 only twenty five holdings throughout the Netherlands had reported outbreaks of the disease at the end of 2007 (Dercksen et al., 2007). The manifestation of clinical signs amongst BTV-8 infected goats in north-western Europe thus appears to have been a relatively rare occurrence. This was confirmed by a sero-prevalence study in the Netherlands (2007) that indicated that goats were infected at a high prevalence (estimated 
at 47\%) (Elbers et al., 2008). A similarly high sero-prevalence (estimated at 25\%) was recorded amongst goats in Germany (Conraths et al., 2009).

Although transplacental infection of sheep and cattle with the European strain of BTV-8 has been demonstrated, no information is currently available on the ability of BTV-8 to infect goats through this route. The ability of BTV -8 to overwinter by infecting goats via the transplacental route may however be significant, especially when considering the high sero-prevalence found amongst goats in Europe during the 2007-2008 outbreak. The present study describes an experiment designed to investigate whether BTV-8 is able to cross the caprine placenta.

\section{Materials and method}

\section{Virus}

Bluetongue virus serotype 8 that was isolated from a clinically affected bovine in the Netherlands in 2007 was used for infection (kindly provided by Dr. A. C. Potgieter, Deltamune, Pretoria, South Africa). The virus was originally isolated (E1/BHK2) at the International Institute for Animal Health, (Pirbright, UK) and is stored with the sample designation NET2007/01. A virus stock for inoculation was prepared by passing the virus twice in African green monkey kidney (Vero) cells (E1/BHK2/V2). Virus containing cell culture supernatant was subsequently titrated in Vero cells by using the endpoint dilution method previously described by Reed and Muench (1938) and diluted in cell culture medium to a final titre of $4.75 \log _{10} \mathrm{TCID}_{50} / \mathrm{ml}$.

African monkey green monkey kidney cells were grown in $75 \mathrm{~cm}^{2}$ flasks containing $30 \mathrm{ml}$ Dulbecco’s Minimal Essential Medium (DMEM) supplemented with 5\% foetal calf serum (v/v), 
$10 \%$ tryptose phosphate broth (v/v) and $1 \mathrm{mg} / \mathrm{ml}$ gentamycin and incubated at $37^{\circ} \mathrm{C}$ in an atmosphere containing $5 \% \mathrm{CO}_{2}$ until $90 \%$ confluent.

\section{Animals}

Non-parous pure-bred Saanen goats between 1 and 2 years of age were used in the trial. The animals were purchased from the Experimental Farm of the University of Pretoria (Pretoria, South Africa). Following clinical examination, the serological status of the animals for BTV was evaluated by using a cELISA (Veterinary Medical Research and Diagnostics, VRMD) and six sero-negative healthy appearing animals selected. The animals were housed in open stables containing black light insect traps and routinely treated with a topical insect repellent (Cylence, Bayers - active ingredient cyfluthrin) in order to minimize Culicoides bites. Oestrus was synchronized, after which the goats underwent intra-cervical insemination with fresh BTV realtime RT-PCR negative semen. Two non-viraemic and sero-negative rams were left with the goats for 24 hours. Twenty nine days later the goats were evaluated for pregnancy by ultrasonography and four pregnant animals selected for inclusion in the challenge phase of the study. The remaining two non-pregnant goats were included as negative controls. The animals were transported to an insect secure BSL-3 holding facility (Onderstepoort Transboundry Animal Diseases Facility, ARC-OVI) where the inoculations were conducted. All animals were accommodated according to the guidelines of the University of Pretoria's Animal Use and Care Committee (AUCC project number V059-10).

\section{Experimental design}


At Day 62 of gestation (day 0 of the study) each pregnant goat was injected with $1 \mathrm{ml}$ of BTV-8 inoculum in the jugular vein and $1 \mathrm{ml}$ subcutaneously on the right side of the neck (total inoculum $=2 \mathrm{ml}$ ). Control animals were inoculated in a similar fashion with BTV negative cell culture medium. From day 1 following challenge, the goats were observed twice daily for clinical signs. In order to investigate infection of the foetuses, the BTV-8 inoculated goats were sequentially euthanised through the intravenous injection of sodium pentobarbitone $(200 \mathrm{mg} / \mathrm{kg})$ at roughly two week intervals post infection [13 (animal 1), 25 (animal 2) and 43 (animals 3 and 4) dpi] and the foetuses and adults examined post mortem. The control animals (animals 5 and 6) were euthanised at the end of the trial (46 dpi).

\section{Sample collection}

Blood samples (EDTA, heparin and serum) were collected from all goats prior to inoculation (day -14 and 0), daily for $21 \mathrm{dpi}$ and weekly thereafter until the experimental endpoints. Skin samples were also taken from each animal on a weekly basis during the first 21 dpi and on the day of euthanasia. At necropsy tissues (skin, brain, submandibular lymph node, tonsils, lung, spleen, kidney, liver, heart, tongue, mammary tissue, uterus, cotyledon, foetal membranes and umbilical cord) and blood samples (EDTA, heparin and serum) were collected from adult goats and foetuses. Each animal was examined separately and the surfaces and instrumentation cleaned between euthanisation. Special care was also taken to avoid contamination of the foetuses with maternal blood.

Competive enzyme linked immunosorbent assay (cELISA) 
Group-specific antibodies to BTV were measured in the goats at different intervals as previously described and in serum from foetuses at necropsy. The presence of group-specific antibodies was assessed using a cELISA (Veterinary Medical Research and Diagnostics, VRMD) according to the manufacturer's instructions. Percentage negativity values were calculated by using the following formula: [1 - (OD sample/ OD negative reference)] x 100 and a cut-off value of $>50 \%$ used to distinguish between positive and negative sera.

\section{Serum neutralization tests}

Each serum sample that tested positive in the cELISA was tested in duplicate for the presence and titre of neutralizing antibodies to BTV-8 using a serum virus neutralization test (SNT) (OIE, 2004).

\section{RNA extraction}

For real-time reverse transcriptase-polymerase chain reaction (real-time RT-PCR) and conventional RT-PCR (for sequencing), two different RNA extraction protocols were followed. For real-time RT-PCR total RNA was extracted from $100 \mu$ l EDTA stabilized blood or $100 \mathrm{mg}$ of tissue (preserved in RNAlater ${ }^{\mathrm{TM}}$, Ambion) by using Trizol (Invitrogen) according to the manufacturer's instructions and resuspended in $50 \mu 1$ AVE buffer (QIAGEN). For conventional RT-PCR, selected blood and tissue samples were extracted several times by using Trizol. Viral double stranded RNA (dsRNA) was thereafter precipitated from total RNA (Potgieter et al., 2009) and concentrated by passing the dsRNA from several extraction replicates through one QIAquick $^{\mathrm{TM}}$ PCR purification column (QIAGEN) prior to washing and elution. 


\section{Real-time RT-PCR targeting segment 5 (NS1)}

Real-time RT-PCR was conducted on extracted total RNA from blood and tissue samples by using a two step procedure (Toussaint et al., 2007). Briefly: Total RNA was denatured with $10 \% \operatorname{DMSO}(\mathrm{v} / \mathrm{v})$ at $95^{\circ} \mathrm{C}$ for three minutes prior to snap cooling on ice. Reverse transcription was thereafter performed on $2 \mu 1$ RNA by using the High Capacity RNA to cDNA master mix (Applied Biosystems) and $1.25 \mu \mathrm{M}$ random hexamers $\left(25^{\circ} \mathrm{C}\right.$ for $5 \mathrm{~min}, 42^{\circ} \mathrm{C}$ for $30 \mathrm{~min}$ and $95^{\circ} \mathrm{C}$ for $5 \mathrm{~min}$ ). Real-time PCR was performed using the TaqMan ${ }^{\circledR}$ Universal Master Mix II (Applied Biosystems) with 10 pmol of each of the primers BTV S5 F1-19 and BTV S5 R76-57, 2.5 pmol TaqMan probe (BTV S5 P 49-27) and $5 \mu \mathrm{l}$ cDNA (20 ul in total). Cycling conditions were as follows; 1 cycle at $95^{\circ} \mathrm{C}$ for $10 \mathrm{~min}$ and 50 cycles at $95^{\circ} \mathrm{C}$ for $15 \mathrm{~s}$ followed by $58^{\circ} \mathrm{C}$ for $1 \mathrm{~min}$. Mammalian beta-actin mRNA was amplified as an internal control by using the same conditions as described above. Samples were considered BTV positive if they demonstrated a cycle threshold $(\mathrm{Ct})$ value $<45$.

\section{Conventional RT-PCR and sequencing}

Conventional PCR was conducted on enriched viral dsRNA (Mertens et al., 2007) from blood samples that were collected from each of the adult goats between 4-15 dpi as well as blood and tissue (cotyledons, placenta, placental fluid, and brain) from foetuses taken at necropsy. These samples had previously demonstrated positive results in the NS1 real-time RT-PCR. Briefly: Double stranded RNA ( $5 \mu 1$ ) was denatured with $1 \mu 10.2 \mathrm{M}$ methyl mercuric hydroxide $(\mathrm{MMOH})$ for 10 minutes at room temperature prior to the addition of $1 \mu 11.0 \mathrm{M} 2-$ mercaptoethanol. Reverse transcription was performed on $5 \mu 1$ denatured dsRNA by using the High Capacity RNA to cDNA master mix (Applied Biosystems) and 10 pmol of each of two 
BTV-8 segment 2-specific primers (BTV-8/2/710F; BTV-8/2/897R) $\left(25^{\circ} \mathrm{C}\right.$ for $5 \mathrm{~min}, 42^{\circ} \mathrm{C}$ for $30 \mathrm{~min}$ and $95^{\circ} \mathrm{C}$ for $5 \mathrm{~min}$ ). Each RT-PCR reaction (total volume of $50 \mu \mathrm{l}$ ) contained $\operatorname{DreamTaq}^{\mathrm{TM}}(2 \mathrm{X})$ Green PCR Master Mix (Fermentas), $20 \mu \mathrm{l}$ of cDNA and 10 pmol of each primer. The thermal profile was: $95^{\circ} \mathrm{C}$ for $5 \mathrm{~min}$; and 40 cycles of $94{ }^{\circ} \mathrm{C}$ for $30 \mathrm{~s}, 50{ }^{\circ} \mathrm{C}$ for $30 \mathrm{~s}$ and $72{ }^{\circ} \mathrm{C}$ for $2.5 \mathrm{~min}$, followed by $72{ }^{\circ} \mathrm{C}$ for $10 \mathrm{~min}$. The PCR products $(10 \mu \mathrm{l})$ were analyzed by $1 \%$ agarose gel electrophoresis and visualized under UV light after staining with ethidium bromide.

Reactions that yielded the correct sized product (approx. 560 base pairs) were purified with a QIAquick® PCR purification kit (QIAGEN). Purified products (10 ng) were sequenced using the V 3.1 BigDye Terminator system (Applied Biosystems) and $2.5 \mathrm{pmol}$ of either the reverse or forward primer. Unincorporated labelled ddNTPs were removed by ethanol-sodium acetate precipitation and the reactions resolved on an ABI 3100 DNA sequencer. Sequences were assembled and trimmed with the Staden package V4.1 (Bonfield et al., 1995) and were subjected to a nucleotide-nucleotide sequence BLAST on the National Centre for Biotechnology website (National Institute for Health, USA) in order to determine the sequence identities. A 499 base pair region of the VP2 encoding gene corresponding to nucleotide position 2163-2661 of BTV-8 was analyzed (results not shown).

\section{Immunohistochemistry}

Immuno-staining was performed on tissue samples preserved in $10 \%$ formalin buffered saline (Sanchez-Cordon et al., 2010). In-house polyclonal antibodies directed towards the viral core protein (VP7) were used at a 1:200 dilution as primary antibodies for antigen detection. The 
immunoperoxidase test showed a strong positive reaction in positive control slides prepared from a clinical bluetongue field case (ovine, South Africa). Only a low level background staining was observed in negative control slides.

\section{Virus isolation}

Virus isolation was attempted from selected blood samples from both adults and foetuses (previously frozen at $-80^{\circ} \mathrm{C}$ ) that demonstrated the lowest $\mathrm{Ct}$ values in the real-time RT-PCR by using Culicoides sonorensis (KC) cells (Wechsler et al., 1989). This was done in an attempt to demonstrate the presence and duration of infectious viraemia. Blood cell pellets (obtained from $1 \mathrm{ml}$ blood) were washed three times with $1 \mathrm{ml}$ Dulbecco's PBS and resuspended in $1 \mathrm{ml}$ supplemented Schneider's Drosophila Medium (Schneider, 1964). Homogenization was performed in $2 \mathrm{ml}$ tissue homogenization tubes (Roche) at $1000 \mathrm{~Hz}$ for $30 \mathrm{~s}$ using a tissue lyser (Precellys) prior to centrifugation at $10000 \mathrm{x}$ g for $10 \mathrm{~min}$. Clarified supernatants $(0.5 \mathrm{ml})$ were inoculated into $90 \%$ confluent $\mathrm{KC}$ cells (that previously tested negative for BTV contamination by using the Toussaint et al., 2007 real-time PCR assay) and incubated at $28^{\circ} \mathrm{C}$ for 7 days. Virus replication was confirmed by real-time RT-PCR (as previously described) on the cell culture supernatant. Total RNA was extracted from $200 \mu 1$ clarified innoculum/supernatant with the Mini Viral RNA extraction kit (QIAGEN). The amount of input RNA for the NS1 real-time RTPCR was standardized following quantification of total RNA by using a UV spectrophotometer. Samples were considered to contain infective viruses if $\mathrm{Ct}$ values in the insect cell culture supernatant decreased relative to that of the original inoculums.

\section{Results}




\section{Clinical signs}

All BTV inoculated goats demonstrated a biphasic rise in body temperature (results not shown). The first rise occurred between 1-3 dpi and a second rise between 6-10 dpi. The temperatures peaked at $8 \mathrm{dpi}$ and dropped back to baseline levels at $11 \mathrm{dpi}$. Only goat number 2 demonstrated temperatures above $40^{\circ} \mathrm{C}$. Goat number 2 also showed moderate enlargement of the lymph nodes and slight hyperaemia/haemorrhage of the conjunctivae between 8-13 dpi. No overt clinical signs (except for an increase in body temperature) were observed in any of the other goats including the negative controls.

\section{Pathology}

Goat number 1 demonstrated hypaeremia and oedema of the right and left cranial lobes of the lung. Froth was also present in the tracheae and bronchi, while focal areas of petechial and ecchymotic haemorrhages (approximately $30 \mathrm{~mm}$ in diameter) were found in the endocardium of the left ventricle of the heart. The goat carried a single foetus (1a) that appeared normal on external and internal examination. Goat number 2 demonstrated multiple petechial haemorrhages in the cortex of the submandibular lymph node as well as in the tonsilar sinuses. The cranial lobes of the lungs were moderately hyperaemic and oedematous (Fig. 1A). The goat was carrying a single foetus (2a) that appeared normal on external examination. Macroscopic lesions observed included atelectasis of the cranial lobes of the lung and a congested friable liver with focal areas of haemorrhage. Goat number 3 demonstrated swollen and haemorrhagic submandibular lymph nodes with multiple petechial haemorrhages in the cortex and medulla. Multiple petechial haemorrhages were also seen in the tonsilar sinuses. The goat was carrying one foetus (3a). The foetus appeared normal externally but demonstrated a congested liver with 
focal areas of haemorrhaging. Localized areas of ecchymotic haemorrhages ( $2 \mathrm{~mm}$ in diameter) were also recorded on the epicardium of the heart along the coronary groove. Goat number 4 demonstrated prominent congestion and petechial haemorrhages in the cortex and medulla of the submandibular lymph nodes (Fig. 1B) as well as focal areas of endocardial petechiation (10 mm in diameter) in both ventricles of the heart (Fig. 1C). The animal carried three foetuses (4a-c) that appeared externally normal. Internally foetus 4 a demonstrated petechiation of the caudal and cranial lobes of the lung (Fig. 1D), a congested haemorrhagic liver (Fig. 1E), a distinct circular haemorrhagic patch (3 $\mathrm{mm}$ in diameter) on the pulmonary artery (Fig. 1F) and localized areas of ecchymotic haemorrhages in the epicardium. The liver also appeared congested and haemorrhagic and had a friable consistency. Foetus $4 \mathrm{~b}$ demonstrated multifocal petechial haemorrhages of all lobes of the lung as well as bilateral pleural haemorrhages (Fig. 1G). The remaining foetus $(4 \mathrm{c})$ similarly demonstrated bilateral pleural haemorrhages, petechiae and ecchymoses on all lobes of the lung, as well as localized areas of petechial and ecchymotic haemorrhages on the epicardium along the right coronary groove and auricles of the heart (Fig. 1H). No pathology was observed in the negative control goats.

\section{Completive enzyme linked immunosorbent assay}

Goat number 4 demonstrated high levels of group-specific antibodies (>80\% negativity) from the initial sampling (day -14) to euthanisation date (43 dpi) (Fig. 2). Goats number 1-3 developed detectable group-specific antibodies (> 50\% negativity) by 6 dpi that reached a plateau at 12 dpi (>80\% negativity). None of the sera that were collected from the foetuses at necropsy tested positive for group-specific antibodies. The negative control animals similarly tested negative for group-specific antibodies against the virus. 


\section{Serum neutralization test}

Neutralizing antibodies against BTV-8 were first detected in three of the inoculated goats at 6-7 dpi (goats 1-3) and reached a maximum titre between 20-28 dpi. The remaining goat (goat 4) demonstrated neutralizing antibodies against BTV-8 as early as 2 dpi that reached a maximum titre at 13 dpi. Neutralizing antibodies were not detected in any of the foetal sera that were harvested at necropsy nor in any of the sera that were collected from the negative control goats.

\section{Real-time reverse-transcriptase PCR}

Bluetongue virus RNA was first detected in the blood of one of the BTV-8 inoculated goats at day -14 (goat 4), at $1 \mathrm{dpi}$ in goat 3 , in one additional goat by 6 dpi (goat 1 ) and in the remaining goat (goat 2) by 7 dpi. Levels of RNA peaked at different time points for the different animals between 7-13 dpi $(\mathrm{Ct}=28.42-34.26)$, after which there was a steady decline until the respective euthanisation dates. All four goats furthermore tested positive for BTV RNA in their blood at the time of euthanisation (13-43 dpi). A summary of the Ct values obtained from blood sampled from the adult goats (0-41 dpi) is presented in Table 1. Bluetongue virus RNA was detected in several tissues harvested from the adult goats including heart, kidney, liver, lung, mammary tissue, spleen, submandibular lymph node, tongue, tonsils and uterus. Viral RNA was also detected in skin samples taken from the goats as early as 7 dpi, with skin samples from at least two goats still testing positive at 24 dpi (Table 2). Three of six foetuses ( $3 a, 4 a$ and $4 c$ ) harvested from two goats (43 dpi) tested positive for viral RNA in either blood and/or tissue samples. Viral RNA was also detected in placental tissue from the two remaining goats (13-25 dpi) (Table 3). Cycle threshold values for the majority of foetal and placental samples were high 
(>38 Ct), with the lowest value being detected in brain tissue harvested from foetus 1a at $43 \mathrm{dpi}$ (day 105 of gestation, $\mathrm{Ct}=31.58$ ). Blood and tissue samples collected from control animals tested negative for BTV viral RNA.

\section{Conventional PCR and sequencing}

Amplification products of the correct size were obtained from blood samples from each of the BTV-8 inoculated adult goats (samples taken between 4-13 dpi) as well as brain tissue from two foetuses ( $3 \mathrm{a}$ and $4 \mathrm{c}, 43 \mathrm{dpi}$ ). Sequencing of amplification products confirmed that all four adult goats and the two foetuses were infected with NET01/2007 (results not shown).

Sequencing furthermore indicated that the virus appears to have been relatively stable during its passage in tissue culture, with only one nucleotide change (silent) having occurred over the 499 bp region of the VP2 gene as compared to the published NET01/2007 reference sequence (Genbank accession number GQ506452).

\section{Virus isolation}

Replicating virus was detected in blood samples that were taken from the four BTV-8 inoculated adult goats between $7-14 \mathrm{dpi}$, and that had previously demonstrated $\mathrm{Ct}$ values from 28 to 33 in the NS1 real-time RT-PCR. Infectious virus could not be demonstrated in any of the foetal blood samples or in blood samples from the negative controls.

\section{Immunohistochemistry}

Lymphatic tissues (lymph nodes, tonsils and spleen) demonstrated activation with the BTV8 inoculated goats showing secondary follicle formation in the cortex and hyperplasia in the 
paracortex of the submandibular lymph nodes. Mild congestion in the lungs and sub-mandibular lymph nodes was also a prominent feature, along with mild focal areas of haemorrhage that were observed in several tissues (skin, pleural membranes, lung and sub-mandibular lymph nodes). Only two foetuses demonstrated specific changes that included mild interstitial haemorrhage in the lungs and pleura ( $4 \mathrm{~b}$ and $4 \mathrm{c}$ ) as well as moderate sinusoidal congestion in the liver (4c). The presence of BTV VP7 antigen could not be demonstrated in any of the tissue sections examined.

\section{Discussion}

The date of inoculation of goats in the present study was chosen to coincide with the developmental stage of the ovine foetus when the most severe neurological malformations would be expected to occur following transplacental infection, but late enough to minimize the chances of abortion. Infection of ewes between days 50-60 of gestation for example has previously been demonstrated to lead to the birth of lambs with severe neurological malformations including hydranencephaly and retinal dysplasia (Young and Cordy, 1964; Richards and Cordy, 1967;

Osburn et al., 1971). In the present study the virus was passaged twice in cell culture to obtain a sufficient viral titre. The World Organization for Animal Health (OIE, 2004) recommends that viraemic blood from infected animals be used as inoculum instead of cell culture passaged virus for BTV challenge studies, as multiple passages of the virus in cell culture may change the virus' phenotypic properties (Flanagan and Johnson, 1995). However, two recent studies have demonstrated that there are no appreciable differences in the progression of the disease in sheep or cattle, when these animals were given either of the two types of inocula (Eschbaumer et al., 2010; Martinelle et al., 2011). Furthermore the low number of cell culture passages which were 
used to prepare the innoculum in this study is unlikely to have affected the phenotype of the virus.

Differences in disease progression as well as virological and serological responses have previously been demonstrated when sheep have been infected intravenously or subcutaneously (Umeshappa et al., 2011). Both routes of inoculation were therefore utilized in the present study in order to maximize the chances of inducing clinical disease in the animals. The inoculation of the goats in the present study with BTV-8 did not result in overt clinical signs and it is unlikely that infection of these animals would have been noticed in the field. This result was not unexpected, as a mostly subclinical/mild disease presentation is characteristic of BTV infection in goats. Several authors have commented on the apparent absence of clinical signs amongst infected goats under field conditions. Clinical signs which have been reported in mildly affected animals have generally been limited to a transient febrile response and mild hyperaemia of the conjunctivae of the oral and nasal mucosa (Spreull, 1905; Luedke and Anakwenze, 1972; Koumbati et al., 1999; Shimshony, 2004; Ting et al., 2005). Acute disease has also been difficult to induce in goats experimentally infected with the European strain of BTV-8. In one study, of two Dutch dairy goats that were inoculated with BTV-8, only one demonstrated mild clinical signs (apathy, dysphagia, diarrhoea and lameness) whereas the other was sub-clinically infected (Backx et al., 2007).

The first rise in body temperature in the BTV-8 inoculated goats was observed between 1-3 dpi and was likely associated with the initial infection and replication. A second rise occurred between 6-10 dpi and likely reflected a more systemic reaction following disseminated infection 
of endothelial cells throughout the body. This second increase in body temperature coincided with an increase in BTV RNA levels in the blood of the animals between 7-13 dpi. A similar close relationship between the level of viral RNA in the blood and the occurrence of fever and clinical signs has previously been reported in experimentally infected sheep and cattle, although it has been pointed out that this correlation is not always clear cut (Darpel et al., 2007).

Goat number 4 retrospectively tested positive for BTV group-specific antibodies and viral RNA prior to inoculation (day -14, 0 dpi), indicating a prior infection with BTV. The goats that were used in the trial were purchased from a known region of BTV endemicity and were tested for their serological status approximately three months (94 days) before challenge. Goat number 4 was probably sub-clinically infected with a field strain of BTV at this stage and had not yet sero-converted for group-specific antibodies against the virus. It is further also possible that the animal became infected when it was housed in the open stables during the synchronisation/AI step and could therefore have been infected while already pregnant. However if this is the case, the infection was sub-clinical as neither a febrile reaction nor clinical signs were noted in this animal during its stabling at the facility. The assay that was used for real-time RT-PCR in this study specifically targets the NS1 gene of BTV, and is thus unable to distinguish between infections caused by different serotypes. We were therefore unable to identify the infecting serotype from an analysis of the viral RNA in the positive blood sample that was collected from the animal prior to inoculation. However, the SNT results from serum collected at day -14 and 0 indicated that the animal had not yet sero-converted for BTV-8, indicating an infection with a different serotype. The prior infection of goat 4 with another serotype did not appear to have affected the animal's susceptibility to infection with BTV-8, as BTV RNA levels in the blood 
increased following BTV-8 inoculation, reflecting the active replication of the virus. The animal did however appear to demonstrate a more rapid serologic response than the other goats, with low titre neutralizing antibodies against BTV-8 being detectable as early as 2 dpi. Bluetongue virus serotypes are divided into distinct nucleotypes based on VP2 nucleotide and amino acid sequences (Maan et al., 2007). It has been demonstrated that viruses which belong to the same nucleotype demonstrate some degree of cross-neutralization in serological assays (Erasmus, 1990). It is possible that the virus strain which previously infected goat number 4 and BTV-8 belong to the same nucleotype and that the earlier detection of BTV-8 specific antibodies in this animal reflects immunological cross-reactivity. Nevertheless, there appeared to be no difference in the clinical signs and/or pathological lesions in this animal, as compared to the other goats. Together these results emphasize prior observations that infection with one serotype does not necessarily confer protection against infection with another (Howell, 1960; Howell et al., 1970; Jeggo and Wardley, 1985; Huismans et al., 1987; Eschbaumer et al., 2011) and highlights the requirement for the pre-screening of animals by using both molecular and serological methods prior to inclusion in BTV challenge studies.

The present study demonstrated relatively milder clinical signs and pathology in BTV-8 infected adult goats than what has previously been observed in experimentally infected sheep and cattle in Europe. All goats demonstrated gross lesions, even though the animals were euthanised several weeks after infection. The similarity and location of the lesions between the animals were striking, especially when considering the near absence of clinical signs at the time of euthanasia. Immunohistochemical staining did not demonstrate the presence of VP7 antigen in any of the tissues examined. Gross lesions and histopathological changes could therefore not be 
unequivocally associated with BTV infection. This result could be explained by the relatively sparse and transient infection of endothelial cells with BTV. It has previously been demonstrated by immuno-staining that viral antigen was only present in endothelial cells in the tissues of experimentally infected sheep for between 3-11 dpi, with labelling dramatically being reduced at 10 dpi (Mahrt and Osburn, 1986). In the present study the animals were euthanised between 13$43 \mathrm{dpi}$, and by that time a reduction in viral antigen in the tissues could be expected. The use of polyclonal antibodies directed against VP7 may also not have been ideal for immuno-staining, as VP7 is expressed at a lower level than non-structural proteins such as NS1/NS2 (van Dijk and Huismans, 1988; Darpel et al., 2009b).

The results of the serological, virological and post mortem examinations of the foetuses are summarized in Table 4. Positive real-time RT-PCR results from foetal blood and tissue samples indicated that transplacental infection had occurred in three foetuses (3a, 4a and 4c) harvested at 43 dpi. As goat number 4 could possibly have been infected with another serotype while pregnant, we partially confirmed this result by conducting RT-PCR and sequencing of BTV segment 2 RNA present in brain tissue taken from foetus $4 c$, which confirmed infection with NET2007/01. We were however unable to obtain segment 2 RT-PCR amplicons from all blood and tissues sampled from the foetuses carried by goat 4 , and it is therefore possible that other real-time PCR positive samples (including those taken from both the adult goat and the remaining foetuses $4 \mathrm{~b}$ and $4 \mathrm{c}$ ) may reflect possible trans-placental infection with the coinfecting serotype. Nevertheless the sequencing results confirmed infection of at least one of the three foetuses with BTV-8. It is unknown whether co-infection with the additional BTV serotype may have influenced the capability of BTV -8 to cross the placenta in this animal and 
this possibility should be explored in further studies. Finally sequencing of the segment 2 amplicon obtained from brain tissue of foetus 3 a further supported our findings that BTV-8 was indeed able to cross the caprine placenta. Finally samples of placental origin from the additional two goats (goats 1 and 2a) also tested positive for virus RNA, although infection of the foetuses themselves could not be demonstrated.

Interestingly none of the infected foetuses tested positive for BTV specific antibodies at necropsy. During the BTV-8 outbreak in Europe it was occasionally observed that transplacentally infected offspring were borne vireamic and/or PCR positive, but failed to demonstrate BTV-specific antibodies. This raised concerns that in utero exposure of the animals to BTV-8 may have lead to the development of immuno-tolerance (De Clercq et al., 2008). Immuno-tolerance and/or persistent/latent infections such as occur during the in utero exposure of cattle to bovine viral diarrhoea virus (BVDV) has not been demonstrated for BTV, despite prior reports of such occurrences (Luedke et al., 1977). The latter result therefore probably reflects the immaturity of the foetal immune system at the time of infection, as production of antibodies in ruminants only starts around mid gestation (Osburn, 1994; Maclachlan et al., 2000).

All six foetuses appeared normal on external examination. Gross lesions were more prominent than in the adult goats and appeared to have become more severe with increasing dpi. Five of six foetuses ( $2 a, 3 a$, and $4 a-c)$ demonstrated lesions that may have been associated with transplacental infection, including haemorrhaging in several tissues, similar to what was observed in the adults. A focal area of haemorrhage was also found on the pulmonary artery in 
foetus $4 \mathrm{a}($ Fig. 1F). This is a common finding in BTV infected sheep and has been considered to be pathognomonic for BT (Erasmus, 1975).

Despite evidence of infection of brain tissue in foetus $3 \mathrm{a}$ and $4 \mathrm{c}$, neurological lesions could not be demonstrated. Notwithstanding the absence of malformation in the present study, the potential teratogenicity of BTV infection in goats cannot be excluded. Documented transplacental infection and associated defects vary widely in sheep and cattle and is therefore unpredictable (Osburn, 1994; Maclachlan et al., 2000). Furthermore, in not all cases where animals were born either viraemic and/or PCR positive during the European outbreak of BTV-8 were nervous system lesions observed (De Clercq et al., 2008; Menzies et al., 2008; SantmanBerends et al., 2010; Saegerman et al., 2010). It is possible that neurological lesions may have become apparent if the infected foetuses were allowed to have developed to term.

Interestingly Chaignat et al., (2009) reported possible transplacental infection associated with Toggenburg Orbivirus (TOV - serotype 25) in goats in Switzerland. A kid that was borne in the vector-free period of the year tested positive for TOV RNA and BTV group-specific antibodies. The animal also demonstrated signs of central nervous system dysfunction and died a few weeks after birth (Chaignat et al., 2009). From field observations it seems possible that TOV can cross the placenta in goats, although this has not been confirmed experimentally (Planzer et al., 2011). Stillbirths and congenital abnormalities have furthermore also been reported in goats in Kuwait, possibly in associations with infections caused by the newly identified BTV-26 (Maan et al., 2011). 
The present study demonstrated for the first time that BTV-8 is able to cross the caprine placenta. The potential consequences for the foetus and overwintering of the virus are difficult to determine from the results of this study, due to the low number of pregnant animals that were included. Infected goat foetuses furthermore demonstrated low viral RNA levels in blood and tissue and would thus likely not have been born viraemic. The implication of these findings with regards to the epidemiology and overwintering of BTV-8 in Europe therefore remains unclear. Future studies should include more pregnant animals and bring foetuses to term, in order to determine (a) whether transplacentally infected kids can be borne viraemic, (b) to evaluate the serological status of transplacentally infected kids at birth, and (c) to document possible BTV-8 associated teratogenecity. Adult goats of different breeds and gestational ages should also be used in order to explore host-specific variables with regards to transplacental infection with BTV-8 in this host species. Finally studies exploring the effects of co-infection with different BTV strains that can or cannot cross the placenta should also be initiated, in order to determine whether co-infection is a predisposing factor for transplacental infection of the virus.

\section{Conflict of interest statement}

None of the authors has any financial or personal relationships that could inappropriately influence or bias the content of the paper.

\section{Acknowledgements and funding}

This project was financially supported by the Norwegian School of Veterinary Science (NVH), Tine Diary Cooperative (Norway), Animalia Meat and Poultry Research Centre 
(Norway) and Torstedt's legacy (Norway). The authors would like to express their gratitude to Dr. Henry Annandale (Onderstepoort, Veterinary Hospital) for his assistance with the artificial insemination of the goats and pregnancy evaluation, as well as the staff at the University of Pretoria Biomedical Research Centre (UPBRC) for taking care of the animals. We would also like to thank the ARC-LNR for allowing us the use of the BSL-3 Transboundry Animal Diseases Facility, as well as Ms. Karen Ebersohn (University of Pretoria) for technical assistance.

\section{References}

Backx, A., Heutink, C.G., van Rooij, E.M., van Rijn, P.A., 2007. Clinical signs of bluetongue virus serotype 8 infection in sheep and goats. The Veterinary Record 161, 591-592.

Backx, A., Heutink, R., van, R.E., van, R.P., 2009. Transplacental and oral transmission of wildtype bluetongue virus serotype 8 in cattle after experimental infection. Veterinary Microbiology 138, 235-243.

Bonfield, J.K., Smith, K.F., Staden, R., 1995. A new DNA sequence assembly program. Nucleic Acids Research 24, 4992-4999.

Borden, E.C., Shoorijeh, S.J., Murphy, F.A., 1971. Physiochemical and morphological relationships of some athropod-borne viruses to bluetongue virus - a new taxonomic group. Physiochemical and serological studies. Journal of General Virology 13, 261-271.

Chaignat, V., Worwa, G., Scherrer, N., Hilbe, M., Ehrensperger, F., Batten, C., Cortyen, M., Hofmann, M., Thuer, B., 2009. Toggenburg Orbivirus, a new bluetongue virus: initial detection, first observations in field and experimental infection of goats and sheep. Veterinary Microbiology 138, 11-19.

Conraths, F.J., Gethmann, J.M., Staubach, C., Mettenleiter, T.C., Beer, M., Hoffmann, B., 2009. Epidemiology of bluetongue virus serotype 8, Germany. Emerging Infectious Diseases $15,433-435$.

Dal Pozzo, F., De Clercq, K., Guyot, H., Vandemeulebroucke, E., Sarradin, P., Vandenbussche , F., Thiry, E., Saegerman, C., 2009. Experimental reproduction of bluetongue virus serotype 8 clinical disease in calves. Veterinary Microbiology 136, 352-358.

Darpel, K.E., Batten, C.A., Veronesi, E., Shaw, A.E., Anthony, S., Bachanek-Bankowska, K., Kgosana, L., Bin-Tarif, A., Carpenter, S., Muller-Doblies, U.U., Takamatsu, H.H., 
Mellor, P.S., Mertens, P.P., Oura, C.A., 2007. Clinical signs and pathology shown by British sheep and cattle infected with bluetongue virus serotype 8 derived from the 2006 outbreak in northern Europe. The Veterinary Record 161, 253-261.

Darpel, K., Batten, C.A., Veronesi, E., Williamson, S., Anderson, P., Dennison, M., Clifford, S., Smith, C., Phillips, L., Bidewell, C., Bachanek-Bankowska, K., Sanders, A., Wilson, A.J., Gubbins, S., Mertens, P.P.C., Oura, C.A., Mellor, P.S., 2009a. Transplacental Transmission of Bluetongue Virus 8 in Cattle, UK. Emerging Infectious Diseases 15, 2025-2028.

Darpel, K., Monaghan, P., Anthony, S., Takamatsu, H., Mertens, P.C., 2009b. BTV in the mammalian host and the induced immune response. In: Mellor , P.S., Baylis, M., Mertens, P.C. (Eds.), Bluetongue. Elsevier Academic Press, London, pp. 265-284.

De Clercq, K., De, L., I, Verheyden, B., Vandemeulebroucke, E., Vanbinst, T., Herr, C., Meroc, E., Bertels, G., Steurbaut, N., Miry, C., De, B.K., Maquet, G., Bughin, J., Saulmont, M., Lebrun, M., Sustronck, B., De, D.R., Hooyberghs, J., Houdart, P., Raemaekers, M., Mintiens, K., Kerkhofs, P., Goris, N., Vandenbussche, F., 2008. Transplacental infection and apparently immunotolerance induced by a wild-type bluetongue virus serotype 8 natural infection. Transboundary and Emerging Diseases 55, 352-359.

Dercksen, D., Groot Nibbelink, N., Paauwe, R., Backx, A., van Rijn, P.A., Vellema, P., 2007. First outbreak of bluetongue in goats in the Netherlands. Diergeneeskd 132, 786-790.

Desmecht, D., Bergh, R.V., Sartelet, A., Leclerc, M., Mignot, C., Misse, F., Sudraud, C., Berthemin, S., Jolly, S., Mousset, B., Linden, A., Coignoul, F., Cassart, D., 2008. Evidence for transplacental transmission of the current wild-type strain of bluetongue virus serotype 8 in cattle. The Veterinary Record 163, 50-52.

Du Toit, R.M., 1944. The transmission of bluetongue and horsesickness by Culicoides. Onderstepoort Journal of Veterinary Science and Animal Industry 19, 7-16.

Elbers, A.R., Popma, J., Oosterwolde, S., van Rijn, P.A., Vellema, P., van Rooij, E.M., 2008. A cross-sectional study to determine the seroprevalence of bluetongue virus serotype 8 in sheep and goats in 2006 and 2007 in the Netherlands. BMC Veterinary Research 4, 33.

Erasmus, B.J., 1975. Bluetongue in sheep and goats. Australian Veterinary Journal 51, 165-170.

Erasmus, B.J., 1990. Bluetongue virus. In: Z.Dinter and B.Morein (Ed.), Virus Infections of Ruminants. Elsevier Science Publishers, New York, pp. 227-237.

Eschbaumer, M., Wackerlin, R., Rudolf, M., Keller, M., Konig, P., Zemke, J., Hoffmann, B., Beer, M., 2010. Infectious blood or culture-grown virus: a comparison of bluetongue virus challenge models. Veterinary Microbiology 146, 150-154.

Eschbaumer, M., Wackerlin, R., Savini, G., Zientara, S., Sailleau, C., Breard, E., Beer, M., Hoffmann, B., 2011. Contamination in bluetongue virus challenge experiments. Vaccine 29, 4299-4301. 
Flanagan, M., Johnson, S.J., 1995. The effects of vaccination of Merino ewes with an attenuated Australian bluetongue virus serotype 23 at different stages of gestation. Australian Veterinary Journal 72, 455-457.

Hofmann, M.A., Renzullo, S., Mader, M., Chaignat, V., Worwa, G., Thuer, B., 2008. Genetic characterization of toggenburg orbivirus, a new bluetongue virus, from goats, Switzerland. Emerging Infectious Diseases 14, 1855-1861.

Howell, P.G., 1960. A preliminary antigenic classification of strains of bluetongue virus. Onderstepoort Journal of Veterinary Science Research 28, 357-363.

Howell, P.G., Kumm, N.A., Botha, M.J., 1970. The application of improved techniques to the identification of strains of bluetongue virus. Onderstepoort Journal of Veterinary Research 37, 59-66.

Huismans, H., Erasmus, B.J., 1981. Identification of the serotype-specific and group-specific antigens of bluetongue virus. Onderstepoort Journal of Veterinary Research 48, 51-58.

Huismans, H., van der Walt, N.T., Cloete, M., Erasmus, B.J., 1987. Isolation of a capsid protein of bluetongue virus that induces a protective immune response in sheep. Virology 157 , 172-179.

Jeggo, M.H., Wardley, R.C., 1985. Bluetongue vaccine: cells and/or antibodies. Vaccine 3, 5758.

Kirkland, P., Hawkes, R.A., 2004. A comparison of laboratory and 'wild' strains of bluetongue virus - is there any difference and does it matter? Veterinaria Italiana 40, 448-455.

Koumbati, M., Mangana, O., Nomikou, K., Mellor, P.S., Papadopoulos, O., 1999. Duration of bluetongue viraemia and serological responses in experimentally infected European breeds of sheep and goats. Veterinary Microbiology 64, 277-285.

Luedke, A.J., Anakwenze, E.I., 1972. Bluetongue virus in goats. American Journal of Veterinary Research 33, 1739-1745.

Luedke, A.J., Jochim, M.M., Jones, R.H., 1977. Bluetongue in cattle: effects of vectortransmitted bluetongue virus on calves previously infected in utero. American Journal of Veterinary Research 38, 1697-1700.

Maan, S., Maan, N.S., Samuel, A.R., Rao, S., Attoui, H., Mertens, P.P., 2007. Analysis and phylogenetic comparisons of full-length VP2 genes of the 24 bluetongue virus serotypes. Journal of General Virology 88, 621-630.

Maan, S., Maan, N.S., Ross-smith, N., Batten, C.A., Shaw, A.E., Anthony, S.J., Samuel, A.R., Darpel, K.E., Veronesi, E., Oura, C.A., Singh, K.P., Nomikou, K., Potgieter, A.C., Attoui, H., van, R.E., van, R.P., De, C.K., Vandenbussche, F., Zientara, S., Breard, E., Sailleau, C., Beer, M., Hoffman, B., Mellor, P.S., Mertens, P.P., 2008. Sequence analysis 
of bluetongue virus serotype 8 from the Netherlands 2006 and comparison to other European strains. Virology 377, 308-318.

Maan, S., Maan, N.S., Nomikou, K., Batten, C., Antony, F., Belaganahalli, M.N., Samy, A.M., Reda, A.A., Al-Rashid, S.A., El, B.M., Oura, C.A., Mertens, P.P., 2011. Novel bluetongue virus serotype from Kuwait. Emerging Infectious Diseases 17, 886-889.

Maclachlan, N.J., Conley, A.J., Kennedy, P.C., 2000. Bluetongue and equine viral arteritis viruses as models of virus-induced fetal injury and abortion. Animal Reproduction Sciences 60-61, 643-651.

Mahrt, C.R., Osburn, B.I., 1986. Experimental bluetongue virus infection of sheep; effect of vaccination: pathologic, immunofluorescent, and ultrastructural studies. American Journal of Veterinary Research 47, 1198-1203.

Martinelle, L., Dal, P.F., Sarradin, P., De, L., I, De, C.K., Thys, C., Ziant, D., Thiry, E., Saegerman, C., 2011. Two alternative inocula to reproduce bluetongue virus serotype 8 disease in calves. Vaccine 29, 3600-3609.

Meiswinkel, R., Baldet, T., De, D.R., Takken, W., Delecolle, J.C., Mellor, P.S., 2008. The 2006 outbreak of bluetongue in northern Europe--the entomological perspective. Preventative Veterinary Medicine 87, 55-63.

Menzies, F.D., McCullough, S.J., McKeown, I.M., Forster, J.L., Jess, S., Batten, C., Murchie, A.K., Gloster, J., Fallows, J.G., Pelgrim, W., Mellor, P.S., Oura, C.A., 2008. Evidence for transplacental and contact transmission of bluetongue virus in cattle. The Veterinary Record 163, 203-209.

Mertens, P.P., Pedley, S., Cowley, J., Burroughs, J.N., Corteyn, A.H., Jeggo, M.H., Jennings, D.M., Gorman, B.M., 1989. Analysis of the roles of bluetongue virus outer capsid proteins VP2 and VP5 in determination of virus serotype. Virology 170, 561-565.

Mertens, P.P.C., Maan, S., Samuel, A., Attoui, H., 2005. Orbivirus, Reoviridae. In Fauquet CM, et al (ed), Virus taxonomy. Eighth report of the International Committee on Taxonomy of Viruses. Elsevier/Academic Press, London, United Kingdom, p 466-483.

Mertens, P.P., Maan, N.S., Prasad, G., Samuel, A.R., Shaw, A.E., Potgieter, A.C., Anthony, S.J., Maan, S., 2007. Design of primers and use of RT-PCR assays for typing European bluetongue virus isolates: differentiation of field and vaccine strains. Journal of General Virology 88, 2811-2823.

OIE, 2004. OIE. Manual for Diagnostic Tests and Vaccines. Fifth edition.

Osburn, B.I., Silverstein, A.M., Prendergast, R.A., Jochim, M.M., Levy, S.J., 1971. Experimental viral-induced congenital encephalopathies. I. Pathology of hydranencephaly and porencephaly caused by bluetongue vaccine virus. Laboratory Investigation 25, 206-210. 
Osburn, B.I., 1994. The impact of bluetongue virus on reproduction. Comp Comparative Immunology, Microbiology \& Infectious Diseases 17, 189-196.

Planzer, J., Kaufmann, C., Worwa, G., Gavier-Widen, D., Hofmann, M.A., Chaignat, V., Thur, B., 2011. In vivo and in vitro propagation and transmission of Toggenburg orbivirus. Research in Veterinary Science 91, e163-e168.

Potgieter, A.C., Page, N.A., Liebenberg, J., Wright, I.M., Landt, O., van Dijk, A.A., 2009. Improved strategies for sequence-independent amplification and sequencing of viral double-stranded RNA genomes. Journal of General Virology 90, 1423-1432.

Purse, B.V., Mellor, P.S., Rogers, D.J., Samuel, A.R., Mertens, P.P., Baylis, M., 2005. Climate change and the recent emergence of bluetongue in Europe. Nature Reviews Microbiology $3,171-181$.

Reed, L.J. and Muench, H. A simple method of estimating fifty percent endpoints. American Journal of Hygiene 27: 493-497, 1938

Richards, W.P.C., Cordy, D.R., 1967. Bluetongue virus infection: pathologic responses of the nervous systems in sheep and mice. Science 156, 635-659.

Saegerman, C., Bolkaerts, B., Baricalla, C., Raes, M., Wiggers, L., De, L., I, Vandenbussche, F., Zimmer, J.Y., Haubruge, E., Cassart, D., De, C.K., Kirschvink, N., 2010. The impact of naturally-occurring, trans-placental bluetongue virus serotype- 8 infection on reproductive performance in sheep. Veterinary Journal 187, 72-80.

Sanchez-Cordon, P.J., Rodriguez-Sanchez, B., Risalde, M.A., Molina, V., Pedrera, M., SanchezVizcaino, J.M., Gomez-Villamandos, J.C., 2010. Immunohistochemical Detection of Bluetongue Virus in Fixed Tissue. Journal of Comparative Pathology 143, 20-28.

Santman-Berends, I.M., van, W.L., Vellema, P., van Rijn, P.A., 2010. Vertical transmission of bluetongue virus serotype 8 virus in Dutch dairy herds in 2007. Veterinary Microbiology $141,31-35$.

Schneider, I., 1964. Differentiation of larval Drosophila eye-antennal discs in vitro. Journal of Experimental Zoology 156, 91-104.

Shimshony, A., 2004. Bluetongue in Israel - a brief historical overview. Veterinaria Italiana 50, 116-118.

Spreull, J., 1905. Malarial catarrhal fever (bluetongue) of sheep in South Africa. Journal of Comparative Pathology and Therapeutics 18, 321-337.

Tabachnick, W., 2004. Culicoides and the global epidemiology of bluetongue virus infection. Veterinaria Italiana 40, 145-150. 
Thiry, E., Sagerman, C., Guyot, H., Kirten, P., Losson, B., Rollin, F., Bodmer, M., Czaplicki, G., Toussaint, J.F., De Clercq, K., Dochy, J.M., Dufrey, J., Gilleman, J.L., Messeman, K., 2006. Bluetongue in northern Europe. The Veterinary Record 159, 327.

Ting, L.J., Lee, M.S., Huang, T.S., Huang, C.C., Kuo, S.T., Lee, F., Jong, M.H., Shiau, J.R., Lin, S.Y., 2005. Identification of bluetongue virus in goats in Taiwan. The Veterinary Record $156,52$.

Toussaint, J.F., Sailleau, C., Breard, E., Zientara, S., De, C.K., 2007. Bluetongue virus detection by two real-time RT-qPCRs targeting two different genomic segments. Journal of Virology Methods 140, 115-123.

Umeshappa, C.S., Singh, K.P., Channappanavar, R., Sharma, K., Nanjundappa, R.H., Saxena, M., Singh, R., Sharma, A.K., 2011. A comparison of intradermal and intravenous inoculation of bluetongue virus serotype 23 in sheep for clinico-pathology, and viral and immune responses. Veterinary Immunology Immunopathology 141, 230-238.

van der Sluijs, M., Timmermans, M., Moulin, V., Noordegraaf, C.V., Vrijenhoek, M., Debyser, I., de Smit, A.J., Moormann, R., 2011. Transplacental transmission of Bluetongue virus serotype 8 in ewes in early and mid gestation. Veterinary Microbiology 149, 113-125.

van Dijk, A.A., Huismans, H., 1988. In vitro transcription and translation of bluetongue virus mRNA. Journal of General Virology 69, 573-581.

Velthuis, A.G.J., Saatkamp, H.W., Mourits, M.C.M., De Koeijer, A.A., Elbers, A.R.W., 2010. Financial consequences of the Dutch bluetongue serotype 8 epidemics of 2006 and 2007. Preventive Veterinary Medicine 93, 294-304.

Vercauteren, G., Miry, C., Vandenbussche, F., Ducatelle, R., Van der Heyden, S., Vandemeulebroucke, E., De, L., I, Deprez, P., Chiers, K., De, C.K., 2008. Bluetongue virus serotype 8 -associated congenital hydranencephaly in calves. Transboundary and Emerging Diseases 55, 293-298.

Wechsler, S.J., McHolland, L.E., Tabachnick, W.J., 1989. Cell lines from Culicoides variipennis (Diptera: Ceratopogonidae) support replication of bluetongue virus. J. Invertebrate Pathology 54, 385-393.

Worwa, G., Hilbe, M., Ehrensperger, F., Chaignat, V., Hofmann, M.A., Griot, C., Maclachlan, N.J., Thuer, B., 2009. Experimental transplacental infection of sheep with bluetongue virus serotype 8 . The Veterinary Record 164, 499-500.

Wouda, W., Roumen, M.P., Peperkamp, N.H., Vos, J.H., van, G.E., Muskens, J., 2008. Hydranencephaly in calves following the bluetongue serotype 8 epidemic in the Netherlands. The Veterinary Record 162, 422-423.

Young, S., Cordy, D.R., 1964. An ovine fetal encephalopathy caused by bluetongue virus. Journal of Neuropathology and Experimental Neurology 23, 635-659. 
Tables:

Table 1: Real-time reverse transcriptase PCR results (NS1) for blood samples taken from adult goats infected experimentally with bluetongue serotype 8 .

\begin{tabular}{|c|c|c|c|c|}
\hline Days post infection & Goat 1 & Goat 2 & Goat 3 & Goat 4 \\
\hline-14 & No Ct & No Ct & No Ct & 37.10 \\
\hline 0 & No Ct & No Ct & No Ct & 39.28 \\
\hline 1 & No Ct & No Ct & 36.72 & 39.50 \\
\hline 2 & No Ct & No Ct & 37.76 & 38.75 \\
\hline 3 & No Ct & No Ct & 38.09 & 39.44 \\
\hline 4 & No Ct & No Ct & 39.12 & 33.78 \\
\hline 5 & No Ct & No Ct & 36.71 & 34.09 \\
\hline 6 & 38.93 & No Ct & 34.86 & 35.23 \\
\hline 7 & 36.77 & 36.83 & 32.40 & 33.38 \\
\hline 8 & 35.86 & 36.10 & 32.81 & 38.32 \\
\hline 9 & 32.81 & 35.80 & 33.05 & 39.33 \\
\hline 10 & 35.87 & 38.41 & 33.08 & No Ct \\
\hline 11 & 37.49 & 38.25 & 31.48 & No Ct \\
\hline 12 & 36.19 & 34.26 & 28.42 & 35.88 \\
\hline 13 & 35.30 & 35.93 & 29.55 & 37.10 \\
\hline 14 & & 38.34 & 30.13 & 38.01 \\
\hline 15 & & 38.05 & 31.35 & 37.60 \\
\hline 16 & & 38.73 & 30.80 & 37.27 \\
\hline 17 & & 38.50 & 32.66 & 38.66 \\
\hline 18 & & 38.53 & 33.78 & 38.24 \\
\hline 19 & & 39.49 & 34.45 & 38.07 \\
\hline 20 & & 42.08 & 33.95 & 40.48 \\
\hline 21 & & 40.32 & 35.51 & 38.26 \\
\hline 24 & & No Ct & No Ct & \\
\hline 25 & & No Ct & 40.42 & \\
\hline 28 & & 38.11 & 39.73 & \\
\hline 42 & & & 36.63 & \\
\hline
\end{tabular}


Table 2: Real-time reverse transcriptase PCR results (NS1) for tissue samples taken from adult goats inoculated with bluetongue virus serotype 8 .

Tissue

Heart

Kidney

Liver

Lung

Mammary tissue

Spleen

Submandibular lymph node

Tongue

Tonsils

Uterus

Skin

\section{Goat 1}

$+$

$+$

$+$

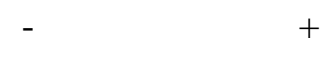

$+$

$+$

$+$

$+$

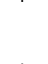

$+$

$+$

$+$

$+$

$+$

$+$
Goat 3

Goat 4

Goat 2

$+$

$+$

$+$

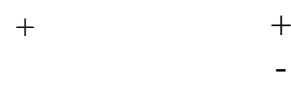

$+$

$+$

$+$

$+$ 
Table 3: Summary of the serological, virological and post mortem findings in goat foetuses

\begin{tabular}{|c|c|c|c|c|c|c|c|}
\hline $\begin{array}{l}\text { Foetus } \\
\text { Number }\end{array}$ & $\begin{array}{l}\text { Days from } \\
\text { inoculation to } \\
\text { euthanasia }\end{array}$ & $\begin{array}{l}\text { Day of } \\
\text { gestation at } \\
\text { euthanasia }\end{array}$ & cELISA/SNT & Blood/Tissue/Fluid & $\begin{array}{l}\text { Real } \\
\text { time RT- } \\
\text { PCR }\end{array}$ & $\begin{array}{l}\text { Conventional } \\
\text { PCR }\end{array}$ & $\begin{array}{l}\text { Gross } \\
\text { pathology }\end{array}$ \\
\hline $1 \mathrm{a}$ & 13 & 75 & Negative & Cotyledon & + & - & None \\
\hline $2 \mathrm{a}$ & 25 & 87 & Negative & Foetal membranes & + & - & Present \\
\hline \multirow[t]{4}{*}{$3 a$} & \multirow[t]{4}{*}{43} & \multirow[t]{4}{*}{105} & \multirow[t]{4}{*}{ Negative } & EDTA Blood & + & \multirow[t]{4}{*}{$\begin{array}{l}\text { Foetal brain } \\
\text { Positive }\end{array}$} & \multirow[t]{4}{*}{ Present } \\
\hline & & & & Cotyledon & + & & \\
\hline & & & & Foetal brain & + & & \\
\hline & & & & Liver & + & & \\
\hline \multirow[t]{4}{*}{$4 a$} & \multirow[t]{4}{*}{43} & \multirow[t]{4}{*}{105} & \multirow[t]{4}{*}{ Negative } & EDTA Blood & + & \multirow[t]{4}{*}{-} & \multirow[t]{4}{*}{ Present } \\
\hline & & & & Cotyledon & + & & \\
\hline & & & & $\begin{array}{l}\text { Amniotic/allantoic } \\
\text { fluid }\end{array}$ & + & & \\
\hline & & & & Umbilical cord & + & & \\
\hline $4 b$ & 43 & 105 & Negative & $\begin{array}{l}\text { All blood/tissue } \\
\text { samples }\end{array}$ & Negative & - & Present \\
\hline $4 c$ & 43 & 105 & Negative & Foetal brain & + & $\begin{array}{l}\text { Foetal brain } \\
\text { positive }\end{array}$ & Present \\
\hline
\end{tabular}

${ }^{a}$ Goat number 4 tested positive for group specific antibodies against BTV prior to inoculation (day 0 ). 


\section{Figure legends}

Fig. 1. Gross pathological findings in adult and foetal goats inoculated with bluetongue virus serotype 8. (Fig. 1A) Moderate hypaeremia and oedema of the cranial lobes of the lungs of goat number 2. (Fig. 1B) Congested submandibular lymph node in goat number 4. (Fig. 1C) Focal areas of endocardial petechiation in the ventricle of the heart of goat number 4. (Fig. 1D) Petechiation of all lobes of the lung in foetus 4a. (Fig. 1E) Congested haemorrhagic liver in foetus 4a. (Fig. 1F) Circular haemorrhagic patch on the pulmonary artery of foetus 4a. (Fig. 1G) Bilateral pleural haemorrhages observed in foetus 4c. (Fig. 1H) Petechial an ecchymotic haemorrhages of the epicardium along the right coronary groove and auricle of the heart of foetus $4 \mathrm{c}$.

Fig. 2. Bluetongue virus group-specific antibody levels in adult goats measured at different intervals between -14 and 22 dpi. A cut-off value of $50 \%$ negativity was used to distinguish between positive and negative samples. 

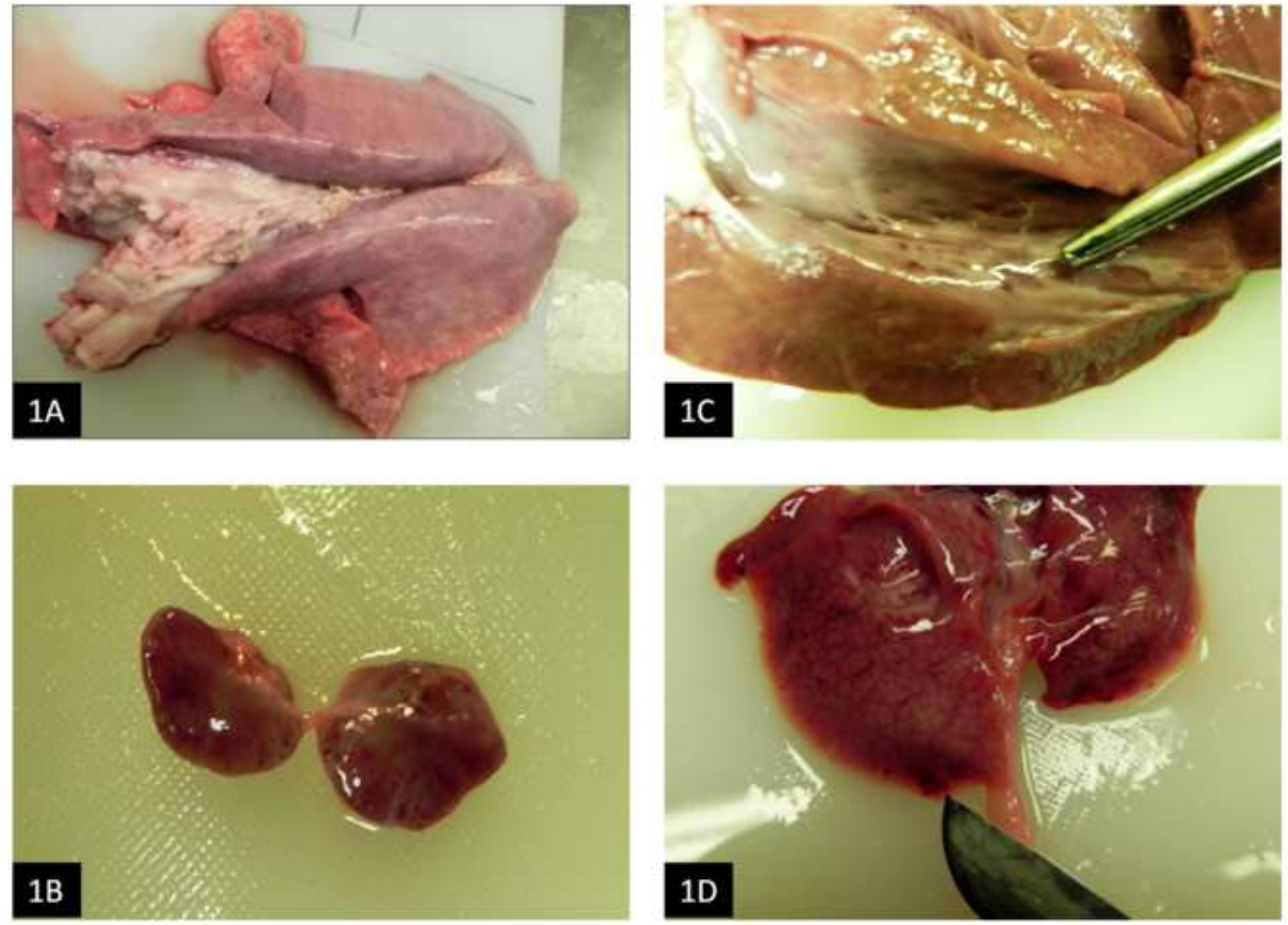




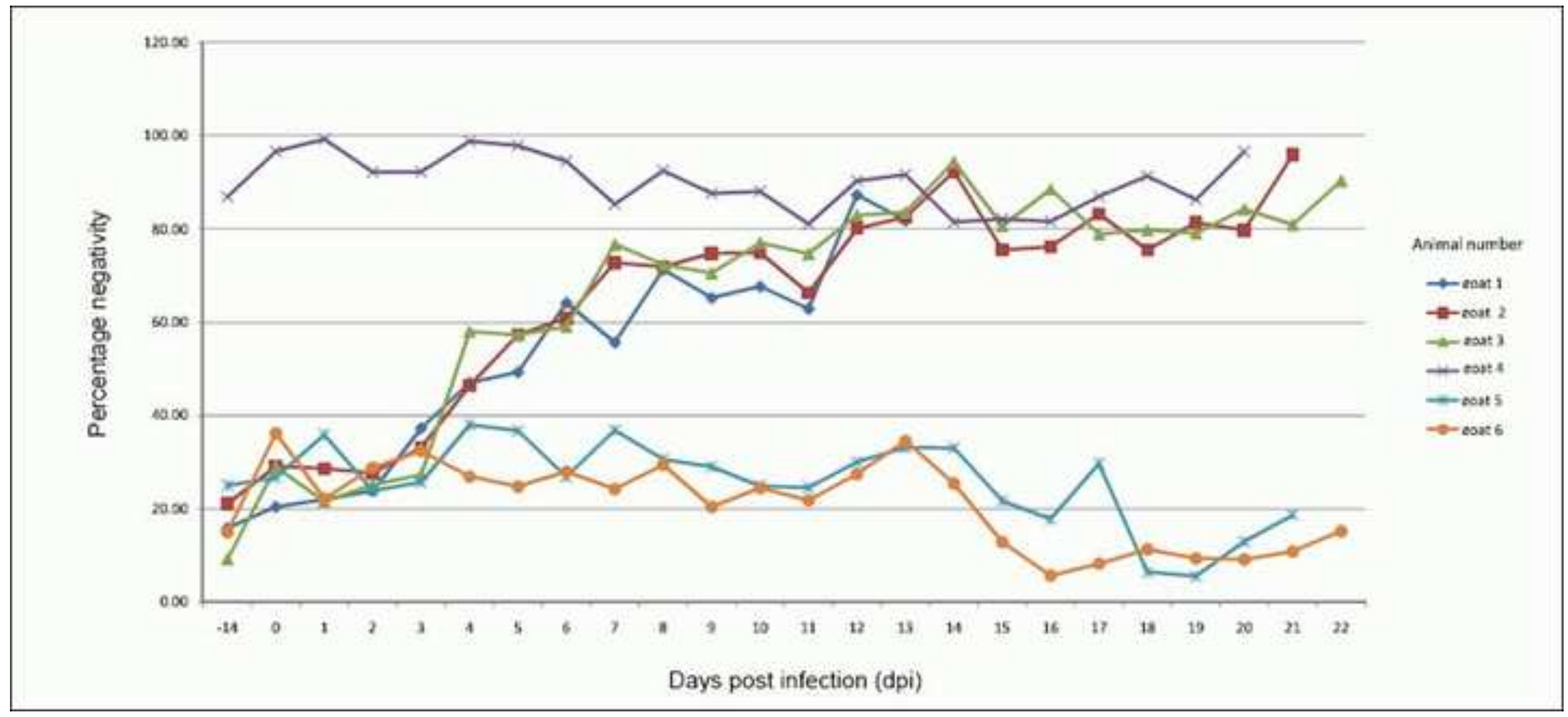

) LJXUHD 